\title{
PENGARUH TEKNIK PROBLEM SOLVING DALAM MENINGKATKAN KEBIASAAN BELAJAR SISWA
}

\author{
Zain Irwanto \\ Fakultas Agama Islam, Universitas Muslim Indonesia \\ Email: lu2gagah@gmail.com
}

\begin{abstract}
The purpose of this study is to obtain a description of student learning habits in SMA Negeri I pangkep, and to determine whether there is influence problem solving techniques in improving student learning habits. This research comparative research is experimental. The sample of research class XI IPS 1 and XI IPS 2 were 32 students. Data collection technique with questionnaire while data analysis used is descriptive analysis, Barleth test and inferential statistical analysis with t-test formula. The results obtained are: the level of student learning habits in SMA Negeri I pangkep Pretest results both the experimental group and the average control group is low. After doing problem solving technique for experiment group, Postest value showed increase of study habits become high, while for control group of Postest value did not show improvement or remain in low category. Similarly, there are differences in learning habits between students who were given problem solving techniques with students who were not given problem solving techniques in SMA Negeri 1 pangkep. That is, for groups of students who are given problem solving techniques, student learning habits show improvement compared with groups of students who are not given problem solving techniques.
\end{abstract}

Keywords: problem solving, study habits, students

\begin{abstract}
ABSTRAK
Tujuan penelitian ini adalah untuk memperoleh gambaran mengenai kebiasaan belajar siswa di SMA Negeri I pangkep, dan untuk mengetahui apakah ada pengaruh teknik problem solving dalam meningkatkan kebiasaan belajar siswa. Penelitian ini penelitian komparatif bersifat eksperimen. Sampel penelitian kelas XI IPS 1 dan XI IPS 2 sebanyak 32 siswa. Teknik pengumpulan data dengan angket sedangkan analisis data yang digunakan adalah analisis deskriptif, uji Barleth dan analisis statistik inferensial dengan rumus t-test. Hasil yang diperoleh yaitu : tingkat kebiasaan belajar siswa di SMA Negeri I pangkep hasil Pretest baik kelompok eksperimen maupun kelompok kontrol rata-rata rendah. Seletah dilakukan teknik problem solving untuk kelompok eksperimen maka nilai Postest menunjukkan peningkatan kebiasaan belajar siswa menjadi tinggi, sedangkan bagi kelompok kontrol nilai Postestnya tidak menunjukkan peningkatan atau tetap dalam kategori rendah. Begitu pula ada perbedaan kebiasaan belajar antara siswa yang diberi teknik problem solving dengan siswa yang tidak diberi teknik problem solving di SMA Negeri 1 pangkep. Artinya, bagi kelompok siswa yang diberikan teknik problem solving, kebiasaan belajar siswa menunjukkan peningkatan dibandingkan dengan kelompok siswa yang tidak diberikan teknik problem solving.
\end{abstract}

Kata kunci : problem solving, kebiasaan belajar, siswa 



\section{PENDAHULUAN}

Dalam perjalanan hidup, setiap orang senantiasa menghadapi masalah, baik itu masalah belajar, masalah pribadi, masalah sosial dan masalah karier. Begitupun dalam masalah belajar di sekolah, diharapkan para siswa dapat mencapai tujuan belajar sebaik-baiknya. Siswa diharapkan dapat belajar dan menguasai bahan pelajaran dengan baik sehingga dapat mencapai hasil yang baik. Aktivitas belajar bagi setiap individu tidak selamanya berlangsung secara wajar. Kadang kala tidak sedikit siswa mengalami kesulitan dalam belajarnya sehingga prestasi yang diperoleh rendah atau di bawah rata-rata kelas.

Salah satu fungsi dalam bimbingan dan konseling adalah fungsi perbaikan/penyembuhan dimana konselor membantu siswa memecahkan masalah yang dihadapinya. Fungsi ini dilakukan oleh konselor dalam menangani masalahmasalah secara individual dan kelompok secara profesional dengan penekanan penggunaan prinsip konseling.

Program bimbingan dan konseling telah dilaksanakan di sekolah-sekolah, namun belum sesuai dengan yang diharapkan. Kenyataan masih banyak siswa tidak yang mengalami masalah tanpa diberikan pelayanan bimbingan dan konseling secara maksimal sehingga masalah yang dihadapi siswa dapat segera teratasi.

Adapun faktor yang mempengaruhi belajar cukup banyak, menurut Daliyono (Benyamin, 2002: 17) faktor-faktor internal (yang bersumber dari dalam diri seseorang) mencakup antara lain; fisiologis, intelegensi, bakat, minat, motivasi, cara belajar, cara atau gaya belajar. Sedangkan faktor-faktor eksternal (bersumber dari luar diri seseorang) meliputi antara lain; keluarga, sekolah, masyarakat, atau lingkungan sekitar, menjadi faktor yang punya pengaruh dalam penentu prestasi belajar siswa.

Pendapat ahli di atas kalau ditelusuri lebih jauh, bahwa rendahnya hasil belajar siswa menurut pengamatan penulis dilapangan kemungkinan penyebabnya antara lain, kurangnya perhatian terhadap pelajaran, penggunaan alat pelajaran yang tidak tepat, mengikuti pelajaran secara tidak serius, belajar tanpa ada pembagian waktu yang tepat, catatan pelajaran yang kurang beres, kurang konsentrasi dalam belajar, kurang memperhatikan tugastugas pelajaran, baru belajar pada saat mau ulangan atau ujian, fasif dalam menerima pelajaran dari guru, malu menanyakan materi pertanyaan yang belum dipahami kepada guru.

Sikap dan kebiasaan belajar sebagai suatu rangkaian aktifitas belajar sangatlah kompleks, karena disamping melibatkan aktivitas mental-fisik juga dipengaruhi berbagai unsur lain di luar dan individu yang belajar. Sikap dan kebiasaan belajar siswa yang mempunyai hasil belajar rendah menampakkan sikap dan kebiasaan belajar yang cenderung negatif berbeda dengan sikap dan kebiasaan belajar siswa yang mempunyai hasil belajar yang tinggi. "Sikap dan kebiasaan belajar yang baik akan menghasilkan hasil belajar yang baik pula dan sebaliknya sikap dan kebiasaan belajar yang negatif akan menghasilkan hasil belajar yang rendah “ (Ahmadi dan Supriono, 1991; 98 ).

Berdasarkan survey pendahuluan melalui wawancara dengan konselor dan dengan 32 orang siswa yang teridentifikasi mengalami kebiasaan belajar yang kurang baik yang dilaksanakan pada tanggal 04 Mei 2009 di SMA Negeri I pangkep, menunjukkan sikap dan kebiasaan belajar tidak tepat waktunya dalam mengerjakan tugas-tugasnya, catatan pelajaran yang kurang beres, tidak ada jadwal belajar, kurangnya konsentrasi dalam belajar, tidak ada keterampilan siswa dalam belajar dan baru belajar pada saat mau ujian.

Menyadari bahwa banyak siswa yang masih memiliki kebiasaan belajar yang kurang baik maka perlu adanya upaya dalam mengatasi masalah ini. Upaya yang dapat dilakukan antara lain memberikan layanan bimbingan kelompok melalui Teknik Problem solving yang belum pernah dilakukan sebelumnya oleh guru pembimbing. Melalui layanan bimbingan kelompok diharapkan dapat membantu siswa dalam merumuskan faktor-faktor yang menyebabkan siswa memiliki kebiasaan belajar yang kurang baik sehingga mampu merumuskan alternati-alternatif pemecahan masalah yang tepat.

Dengan Teknik Problem solving ini di mana siswa akan mengikuti langkah-langkah teknik ini secara sistimatis untuk menangani masalah kebiasaan belajar yang kurang baik, mulai dari siswa mengidentifikasi dan merumuskan masalah yang dihadapinya, mencari 
sumber atau sebab masalahnya, mencari alternatif pemecahan masalahnya, menguji kekuatan dan kelemahan masing-masing alternatif yang dibuat, memilih dan melaksanakan alternatif yang paling menguntungkan dan mengadakan penilaian dari hasil yang dicapai.

Dalam upaya pemecahan masalah yang terjadi pada siswa yang memiliki kebiasaan belajar yang kurang baik, maka peneliti ingin memberikan teknik pemecahan masalah (teknik problem solving) untuk membantu siswa dan memecahkan masalah kebiasaan belajar yang kurang baik pada dirinya, maka diharapkan dalam pelaksanaan pemberian teknik problem solving siswa dan guru pembimbing bekerjasama untuk mendapatkan alternatif-alternatif pemecahan masalah sehingga kebiasaan belajar menjadi baik.

Untuk itu, penulis merasa tertarik mencoba mengkaji lewat kajian empirik mengenai pengaruh teknik problem solving dalam meningkatkan kebiasaan belajar siswa. Untuk pemilihan lokasi dengan pertimbangan bahwa di SMA Negeri I pangkep merupakan tempat penulis di tempatkan melakukan praktek PPL sekolah karena sekolah ini memiliki keunggulan tenaga, fasilitas yang lengkap, dan komitmen terhadap pelaksanaan konseling, dalam prakteknya teknik ini belum pernah dilaksanakan di sekolah ini. Berkaitan dengan hal itu, penulis terinspirasi untuk mengkaji melalui penelitian dengan pendekatan eksperimen, dengan judul "Pengaruh Teknik Problem Solving dalam meningkatan kebiasaan belajar siswa di SMA Negeri I pangkep".

Tujuan yang ingin dicapai dalam pelaksanaan penelitian ini adalah sebagai (1) Untuk mengetahui gambaran kebiasaan belajar siswa di SMA Negeri I pangkep. (2) Untuk mengetahui apakah ada pengaruh Teknik Problem Solving dalam meningkatan kebiasaan belajar siswa di SMA Negeri I pangkep. Hipotesis penelitian ini yaitu"ada pengaruh teknik problem solving dalam meningkatkan kebiasaan belajar siswa di SMA Negeri I pangkep ".

\section{METODE}

Pendekatan yang digunakan dalam penelitian ini adalah pendekatan eksperimen dengan desain komparatif. Artinya, penelitian ini membandingkan dalam meningkatkan kebiasaan belajar siswa antara yang diberikan teknik problem solving dengan yang tidak diberikan teknik problem solving di SMA Negeri I pangkep . Dengan demikian, dalam penelitian ini ada kelompok eksperimen dan kelompok kontrol yang masing-masing diberikan pre test dan post test. Model rancangan penelitian ini adalah pretest -posttest control group design yang dapat di gambarkan sebagai berikut :

Tabel 3.1 Model Rancangan Penelitian

\begin{tabular}{|c|c|c|c|}
\hline Kelompok & Pre test & Perlakuan & Post test \\
\hline Eksperimen (E) & $\mathrm{O}_{1}$ & $X$ & $\mathrm{O}_{3}$ \\
\hline Kontrol (K) & $\mathrm{O}_{2}$ & & $\mathrm{O}_{4}$ \\
\hline
\end{tabular}

(Sumber : Sugiono, 2007: 112)

Dimana :
$\mathrm{E}=$ Kelompok eksperimen
$\mathrm{K}=$ Kelompok kontrol
$\mathrm{O}_{1}=$ Pre test kelompok eksperimen
$\mathrm{O}_{2}=$ Pre test kelompok kontrol
$\mathrm{O}_{3}=$ Post test kelompok eksperimen
$\mathrm{O}_{4}=$ Post test kelompok kontrol
$\mathrm{X}=$ Perlakuan 
Untuk lebih jelasnya berikut disajikan diagram dari penelitian ini

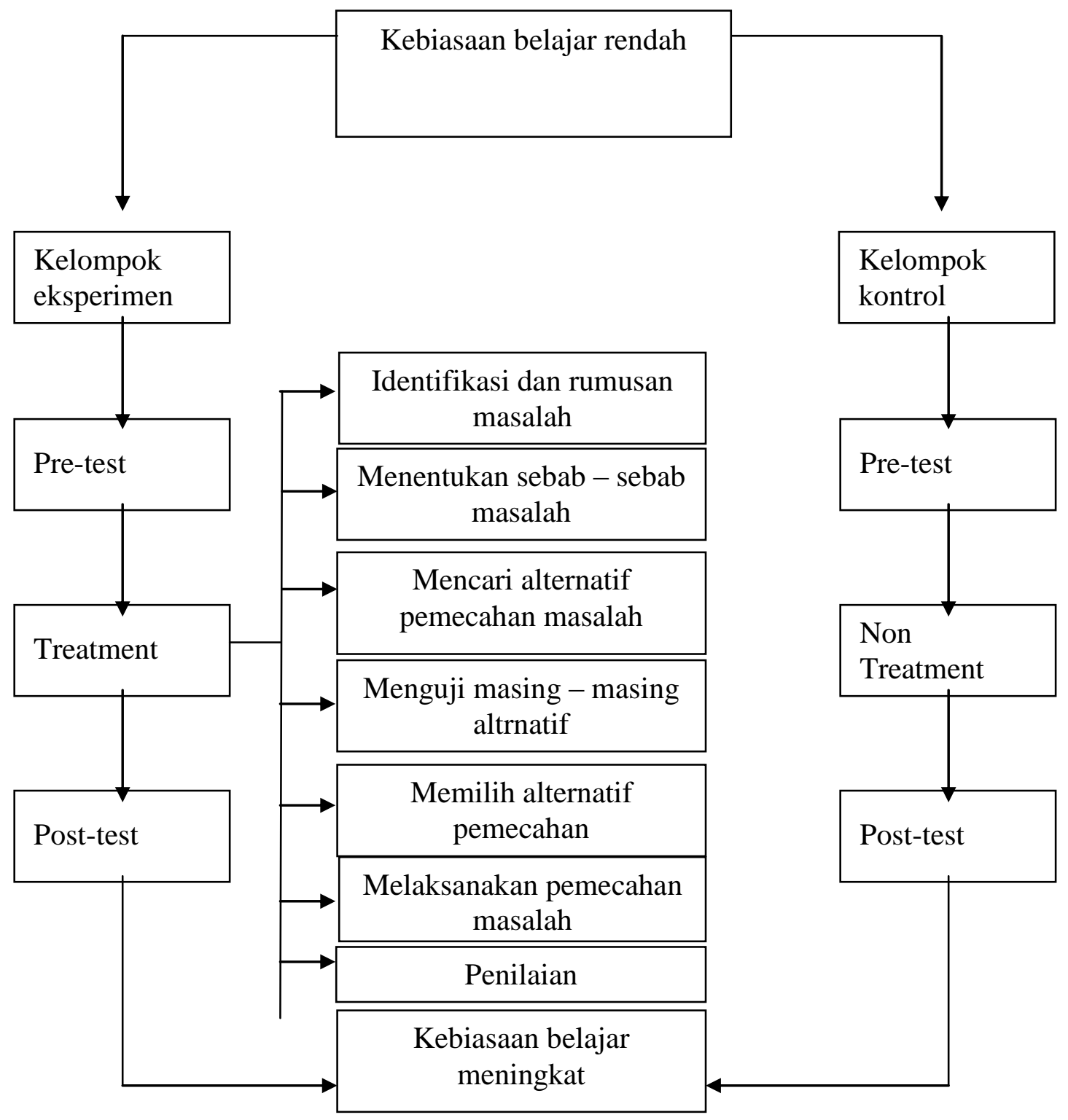

Gambar 3.2 :Diagram Penelitian

Adapun prosedur pelaksanaan penelitian mulai dari penentuan kelompok eksperimen dan kontrol Pre Test, perlakuan berupa teknik problem solving dan Post Test sebagai berikut:

1. Penentuan kelompok eksperimen dan kelompok kontrol dengan teknik proposive sampling yaitu kelas XI. IPS.1 sebagai kelompok eksperimen dan kelas XI. IPS.2 sebagai kelompok kontrol dengan jumlah siswa yang berimbang masing-masing 16 orang

2. Pelaksanaan pre test terhadap kelompok kontrol dan kelompok eksperimen berupa pemberian angket yang berisi pertanyaan tentang kebiasaan belajar.

3. Pemberian teknik Problem solving terhadap kelompok eksperimen adalah sebagai berikut :

a. Langkah 1: Mengidentifikasi dan merumuskan masalah.

b. Langkah 2 : Menentukan sebabsebab masalah.

c. Langkah 3 : Mencari alternatif pemecahan masalah.

d. Langkah 4 : Menguji masingmasing alternatif 
e. Langkah 5 : Memilih alternatif pemecahan

f. Langkah 6 : Melaksanakan alternatif pemecahan

g. Langkah 7 : Penilaian

2. Pelaksanaan Post test terhadap kelompok kontrol dan kelompok eksperimen berupa pemberian angket yang berisi pertanyaan tentang kebiasaan belajar.

3. Untuk kebutuhan analisis data dicari selisih skor Post test dan Pre test untuk masing- masing subjek baik kelompok eksperimen maupun kelompok kontrol nilai selisih (gain skor) inilah yang akan dibandingkan melalui t-test.

Subjek penelitian terdiri dari dua kelas yaitu kelas XI IPS 1 dan XI IPS 2. Langkah yang ditempuh meliputi: (1) berdasarkan hasil wawancara dengan guru pembimbing SMA Negeri I pangkep , (2) memilih dua kelas di semua kelas yang ada di kelas XI.

Tabel 3.2. Penyebaran siswa yang menjadi subjed penelitian

\begin{tabular}{c|c|c|c|c}
\hline \multirow{2}{*}{ No. } & \multirow{2}{*}{ Kelas } & \multicolumn{2}{|c|}{ Jenis Kelamin } & \multirow{2}{*}{ Jumlah Siswa } \\
\cline { 3 - 4 } & Laki-Laki & Perempuan & 16 \\
\hline 1. & XI. IPS.1 & 9 & 7 & 16 \\
\hline
\end{tabular}

Sumber : Tata Usaha SMA Negeri I pangkep

Subjek penelitian dipilih dengan pertimbangan bahwa kedua kelompok tersebut memiliki karakteristik yang sama yaitu memiliki kebiasaan belajar yang rendah, umumnya relatif sama masing-masing kelas XI IPS, selanjutnya diambil siswa sebanyak 16 orang untuk masingmasing kelas XI IPS I dan XI IPS 2 dengan menggunakan teknik Purposive Sampling. Penetapan ke 16 orang setiap kelas berdasarkan alas an tertentu yaitu bahwa ke 32 siswa tersebut termasuk anak yang memiki kebiasaan belajar yang rendah (hasil wawancara dengan konselor) berdasarkan hasil wawancara dengan konselor sehingga ditetapkan 16 orang setiap kelas untuk masing-masing kelompok eksperimen dan kelompok kontrol.

Ada dua jenis instrumen yang digunakan dalam penelitian ini, yaitu bahan perlakuan dan instrumen pengumpulan data.

\section{Pengembangan bahan perlakuan}

Panduan teknik problem solving dibuat oleh peneliti sendiri yang didalamnya mengacu pada langkah-langkah pelaksanaan teknik problem solving secara sistimatis mulai dari mengidentifikasi masalah, merumuskan masalah, menentukan sebab-sebab masalah, mencari alternatif pemecahan masalah, menguji masingmasing alternatif pemecahan masalah, memilih alternatif pemecahan masalah yang tepat, melaksanakan pemecahan masalah, dan penilaian dengan mengacu pada teori dan praktek bimbingan kelompok (Tatiek Romlah, 1987).

Pengembangan instrumen penelitian
Angket kebiasaan belajar merupakan pengukuran yang mengukur tingkat kebiasaan belajar siswa yang dibagi dalam beberapa aspek Delay Avoidance (DA) yang mengukur ketepatan dalam menyelesaikan tugas akademik, menghindarkan diri dari menunda pengerjaan tugas, menghilangkan rangsangan yang mengganggu konsentrasi belajar, dan aspek Work Methods ( WM) yang mengukur penggunaan prosedur belajar yang efektif, efesiensi dalam mengerjakan tugas akademik, serta ketermpilan belajar, yang setiap item pertanyaan dilengkapi dengan berbagai pilihan jawaban yaitu pilaihan tidak pernah (TP), kadang-kadang (KK), sering (S), sangat sering (SS). Sebelum angket digunakan untuk penelitian lapangan untuk mengetahui, angket terlebih dahulu divalidasi oleh dosen validasi psikologi pendidikan dan bimbingan, kemudian diuji coba di lapangan untuk mengetahui validitas dan realibilitas amgket.

Teknik analisis data yang digunakan terdiri atas teknik analisis statistikdeskriptif dan analisis statistik inferensial yaitu statistik inferensial dengan t-test untuk pengujian hipotesis.

Analisis statistik deskriptif untuk menggambarkan kebiasaan belajar siswa di SMA Negeri I Makassar, baik terhadap kelompok eksperimen maupun kelompok kontrol yaitu hasil pretest dan posttest. Untuk itu, dibuatkan tabel distribusi frekuensi dan persentase dan 
masing-masing peubah dibagi atas empat kategori pengukuran peubah.

Pengukuran peubah kebiasaan belajar dengan menggunakan angket sebanyak 35 pertanyaan. Adapun pengkategorian nilainya yaitu : tidak pernah (35-58), kadang-kadang (6186), sering (87-112), sangat sering (113-140). Guna memperoleh gambaran umum tingkat kebiasaan belajar siswa, maka dilakukan perhitungan rata-rata,

Uji homogenitas varians dilakukan unruk mengetahui apakah data yang diperoleh homogen atau tidak dari dua atau lebih kelompok sample. Uji humogenitas dilakukan data yang diperoleh dari hasil angket sebagai berikut. Untuk uji homogenitas digunakan uji Bartlett, yaitu :

a.

$$
\mathrm{X}^{2}=(1 \mathrm{n} 10)\left[\beta-\sum(\mathrm{db}) \log \mathrm{Si}^{2}\right.
$$$$
\text { (Ridwan, } 2007: 185 \text { ) }
$$

Dengan 1n $10=2,3026$ disebut logaritma dalam dari pada pilihan 10 . Dasar penelitiannya dengan taraf nyata $\alpha$,ditolak hipotesis jika $\mathrm{Y}^{2} \geq \mathrm{Y}^{2}(1-\alpha)$ $(\mathrm{k}-1)$ dimana $\mathrm{X}^{2}(1-\alpha)$ dan $\mathrm{dk}=(\mathrm{k}-1)$ Analisis statistik inferensial dimaksudkan untuk menguji hipotesis dengan menggunakan t-test yaitu untuk pengujian hipotesis menggunakan mean dari gainscore (Huck dan Cormier, dkk, 1974) yaitu rata-rata dari selisih skor Pre-test dan Post-test dalam meningkatkan kebiasaan belajar siswa yang diberi dan yang tidak diberi perlakuan berupa teknik problem solving.

Adapun tingkat signifikansi yang digunakan yaitu $\alpha 0,05$ dengan kriteria adalah "Tolak Ho jika t-hitung $\geq \mathrm{t}$-tabel dan terima Ho jika t-hitung $<$ t-tabel" (Sugiyono, 2005:136)

\section{HASIL DAN PEMBAHASAN}

\section{Hasil}

Hasil penelitian yang dilaksanakan di SMA Negeri I pangkep guna mengetahui tingkat kebiasaan belajar siswa melalui pendekatan eksperimen dengan memberikan perlakuan berupa teknik problem solving selama 7 tahap. Hasil penelitian tersebut disajikan dalam bentuk analisis statistik deskriptif, baik kelompok eksperimen maupun kelompok kontrol dan t-test untuk pengujian hipotesis.

Analisis statistik deskriptif dimaksudkan untuk memperoleh gambaran tingkat kebiasaan belajar siswa di SMA Negeri I pangkep , baik kelompok eksperimen maupun kelompok kontrol, baik hasil Pretest maupun Pretest.

a. Kebiasaan belajar siswa pada kelompok eksperimen.

Kebiasaan belajar siswa pada kelompok eksperimen diperoleh berdasarkan hasil Pretest yang dilaksanakan pada hari Sabtu Tanggal 10 Oktober 2009 dan Posttest pada hari Sabtu 14 November terhadap 32 siswa di SMA Negeri I pangkep .

Berikut ini disajikan data kebiasaan belajar siswa di SMA Negeri I pangkep kelompok eksperimen sebelum dan sesudah penggunaan teknik problem solving yang disajikan dalam bentuk tabel distribusi frekuensi dan persentase dengan berdasarkan data penilitian pada lampiran III.

Tabel 4.1 Tingkat Kebiasaan belajar siswa di SMA Negeri I pangkep kelompok eksperimen hasil Pretest dan Postest.

\begin{tabular}{l|l|l|l|l|l}
\hline \multirow{2}{*}{ Interval } & \multirow{2}{*}{$\begin{array}{l}\text { Kebiasaan } \\
\text { belajar siswa }\end{array}$} & \multicolumn{3}{|l}{ Kelompok Eksperimen } \\
\cline { 3 - 6 } & & Pretest & \multicolumn{2}{l}{ Postest } \\
\cline { 3 - 6 } & & Frekuensi & Persentase & Frekuensi & Persentase \\
\hline $113-140$ & Sangat tinggi & 0 & 0 & 0 & 0 \\
$87-112$ & Tinggi & 0 & 0 & 6 & 37,5 \\
$61-86$ & Cukup & 5 & 31,25 & 10 & 62,5 \\
$35-60$ & Rendah & 11 & 68,75 & & 0 \\
\hline Jumlah & 16 & 100,00 & 16 & 100,00 \\
\hline
\end{tabular}

Sumber : Hasil angket kelompok eksperimen 
Kebiasaan belajar siswa siswa mengemukakan masalahnya pada konselor di SMA Negeri I pangkep untuk kelompok eksperimen saat Pretest secara umum dalam kategori cukup sebanyak 5 responden atau 31,25 persen, kategori rendah sebanyak 11 responden atau 68,75 persen. Namun setelah diberikan perlakuan berupa teknik problem solving sebanyak 7 tahap, maka tingkat kebiasaan belajar siswa menunjukkan peningkatan yang berarti, dimana yang dominan sebanyak 10 responden atau 62,5 persen kategori cukup dan 6 responden atau 37,5 persen kategori tinggi.

b. Tingkat kebiasaan belajar siswa pada kelompok kontrol.
Kebiasaan belajar siswa pada kelompok kontrol yang dilakukan secara bersamaan terhadap kelompok eksperimen yang diperoleh berdasarkan hasil Pretest yang dilaksanakan pada hari Sabtu Tanggal 10 Oktober 2009 dan Postest pada hari Kamis Tanggal 19 November 2009 terhadap 16 siswa di SMA Negeri I pangkep .

Berikut ini disajikan data tingkat kebiasaan belajar siswa di SMA Negeri I pangkep kelompok kontrol hasil Pretest dan Postest dimana kelompok kontrol tidak diberikan perlakuan berupa teknik problem solving, yang disajikan dalam bentuk tabel distribusi frekuensi dan persentase dengan berdasarkan data penelitian pada lampiran III.

Tabel 4.2 Tingkat kebiasaan belajar siswa di SMA Negeri I pangkep kelompok kontrol hasil Pretest dan Postest.

\begin{tabular}{l|l|l|l|l|l}
\hline \multirow{2}{*}{ Interval } & \multirow{2}{*}{$\begin{array}{l}\text { Kebiasaan } \\
\text { belajar siswa }\end{array}$} & \multicolumn{4}{|c}{ Kelompok Kontrol } \\
\cline { 3 - 6 } & & Frekuensi & Persentase & Frekuensi & Persentase \\
\cline { 3 - 6 } & & 0 & 0 & 0 & \\
\hline $113-140$ & Sangat tinggi & 0 & 0 & 0 & \\
$87-112$ & Tinggi & 2 & 12,5 & 3 & 18,75 \\
$61-86$ & Cukup & 14 & 87,5 & 13 & 81,25 \\
$35-60$ & Rendah & 16 & 100,00 & 16 & 100,00 \\
\hline Jumlah & & &
\end{tabular}

Sumber : Hasil angket kelompok kontrol

Tingkat kebiasaan belajar siswa untuk kelompok kontrol saat Pretest secara umum dalam kategori rendah sebanyak 14 responden atau 87,5 persen dan bahkan terdapat 2 responden atau 12,5 persen yang kategori cukup pada kebiasaan belajar pada siswa. Namun saat Postest kondisi tersebut tidak menunjukkan perubahan yang berarti bahkan sedikit menurun, dimana yang dominan sebanyak 13 responden atau 81,25 persen dalam kategori rendah dan hanya 3 responden atau 18,75 persen pada kategori cukup.
Kriteria pengujian yaitu dapat dinyatakan homogen jika nilai signifikansi yang diperoleh lebih besar dari 0,05. Berdasarkan hasil perhitungan (Lampiran IV), diperoleh nilai sebesar 0,975 atau lebih besar dari 0,05, maka dapat disimpulkan bahwa data tingkat kebiasaan belajar pada kelompok eksperimen dan kelompok kontrol mempunyai varian sama atau homogen.

Hipotesis nihil (Ho) penelitian ini adalah "Tidak ada pengaruh teknik problem solving dalam meningkatkan kebiasaan belajar siswa di SMA Negeri I pangkep ".

Berdasarkan hasil perhitungan t-test pada lampiran $\mathrm{V}$, diperoleh nilai $\mathrm{t}$ hitung 
sebesar 26,358 sedangkan nilai t tabel pada taraf signifikansi 5 persen dengan $\mathrm{dk}=60$ atau nilai t sebesar 2,000 pada lampiran VI yang berarti nilai $t$ hitung lebih besar dari pada nilai $\mathrm{t}$ tabel, maka sebagai konsekuensinya maka hipotesis nihil yaitu "tidak ada pengaruh teknik problem solving dalam meningkatkan kebiasaan belajar siswa di SMA Negeri I pangkep ," dinyatakan ditolak dan konsekuensinya hipotesis kerja (Hi) yaitu "Ada pengaruh teknik problem soving dalam meningkatkan kebiasaan belajar siswa di SMA Negeri I pangkep ", dinyatakan diterima.

Pengujian hipotesis dengan menggunakan mean dari gainscore yaitu rata-rata dari selisih skor Pretest dan Posttest yang menunjukkan pengaruh teknik problem solving dalam meningkatkan kebiasaan belajar siswa di SMA Negeri I pangkep. Berdasarkan hasil Pretest dan Posttest pada kelompok eksperimen semuanya mengalami peningkatan pada 16 subjek penelitian sedangkan pada kelompok kontrol tidak terdapat peningkatan yang berarti.

Pada kelompok eksperimen responden 1 dengan tingkat kebisaan belajar memperoleh skor 45 berdasarkan hasil Pretest, jika dihubungkan dengan tabel 4.1 maka dia berada pada kategori rendah kemudian hasil Posttest sebesar 77 pada kategori cukup. Responden 2 dengan skor Prestest sebesar 64 yang berada pada kategori sedang juga mengalami peningkatan keterbukaan diri sebesar 88 hasil Posttest yang pada kategori tinggi. Responden 3 dengan skor Prestest sebesar 56 yang berada pada kategori rendah juga mengalami peningkatan kebiasaan belajar sebesar 88 hasil Posttest yang pada kategori tinggi. Responden 4 dengan skor Prestest sebesar 50 yang berada pada kategori rendah juga mengalami peningkatan kebiasaan belajar sebesar 76 hasil Posttest yang pada kategori cukup. Responden 5 dengan skor Prestest sebesar 54 yang berada pada kategori rendah juga mengalami peningkatan kebiasaan belajar sebesar 68 hasil Posttest yang pada kategori cukup.

Responden 6 dengan skor Prestest sebesar 54 yang berada pada kategori rendah juga mengalami peningkatan kebiasaan belajar sebesar 102 hasil Posttest yang pada kategori tinggi. Responden 7 dengan skor Prestest sebesar 52 yang berada pada kategori rendah juga mengalami peningkatan kebiasaan belajar sebesar 82 hasil Posttest yang pada kategori cukup. Responden 8 dengan skor Prestest sebesar 63 yang berada pada kategori cukup juga mengalami peningkatan kebiasaan belajar sebesar 78 hasil Posttest yang tetap pada kategori cukup. Responden 9 dengan skor Prestest sebesar 52 yang berada pada kategori rendah juga mengalami peningkatan kebiasaan belajar sebesar 68 hasil Posttest yang pada kategori cukup. Responden 10 dengan skor Prestest sebesar 69 yang berada pada kategori cukup juga mengalami peningkatan kebiasaan belajar sebesar 107 hasil Posttest yang pada kategori tinggi.

Responden 11 dengan skor Prestest sebesar 44 yang berada pada kategori rendah juga mengalami peningkatan kebiasaan belajar sebesar 87 hasil Posttest yang pada kategori cukup. Responden 12 dengan skor Prestest sebesar 50 yang berada pada kategori rendah juga mengalami peningkatan kebiasaan belajar sebesar 88 hasil Posttest yang pada kategori tinggi. Responden 13 dengan skor Prestest sebesar 37 yang berada pada kategori rendah juga mengalami peningkatan kebiasaan belajar sebesar 65 hasil Posttest yang pada kategori cukup. Responden 14 dengan skor Prestest sebesar 54 yang berada pada kategori rendah juga mengalami peningkatan kebiasaan belajar sebesar 79 hasil Posttest yang pada kategori cukup. Responden 15 dengan skor Prestest sebesar 49 yang berada pada kategori rendah juga mengalami peningkatan keterbukaan diri sebesar 76 hasil Posttest yang pada kategori cukup dan pada responden 16 dengan skor Prestest sebesar 30 yang berada pada kategori rendah juga mengalami 
peningkatan kebiasaan belajar sebesar 65 hasil Posttest yang pada kategori cukup.

Pada kelompok kontrol responden 1 dengan tingkat kebiasaan belajar memperoleh skor 40 berdasarkan hasil Pretest, jika dihubungkan dengan tabel 4.2 maka dia berada pada kategori rendah kemudian hasil Posttest sebesar 41 pada kategori tetap rendah. Responden 2 dengan skor Pretest sebesar 42 berada pada kategori rendah tidak mengalami peningkatan kebiasaan belajar sebesar 42 hasil Posttest yang berada pada kategori tetap rendah. Responden 3 dengan skor Pretest sebesar 45 berada pada kategori rendah juga tetap tidak mengalami peningkatan kebiasaan belajar sebesar 45 hasil Posttest yang berada pada kategori tetap rendah. Responden 4 dengan skor Pretest sebesar 35 berada pada kategori rendah juga tetap tidak mengalami peningkatan kebiasaan belajar sebesar 38 hasil Posttest yang berada pada kategori tetap rendah. Responden 5 dengan skor Pretest sebesar 40 berada pada kategori rendah juga tetap tidak mengalami peningkatan kebiasaan belajar sebesar 41 hasil Posttest yang berada pada kategori rendah.

Responden 6 dengan skor Pretest sebesar 52 berada pada kategori rendah juga tetap tidak mengalami peningkatan kebiasaan belajar sebesar 55 hasil Posttest yang berada tetap pada kategori rendah. Responden 7 dengan skor Pretest sebesar 58 berada pada kategori rendah juga tetap mengalami peningkatan keterbukaan diri sebesar 49 hasil Posttest yang berada tetap pada kategori rendah. Responden 8 dengan skor Pretest sebesar 47 berada pada kategori rendah juga tetap tidak mengalami peningkatan kebiasaan belajar sebesar 49 hasil Posttest yang berada tetap pada kategori rendah. Responden 9 dengan skor Pretest sebesar 42 berada pada kategori rendah juga tetap tidak mengalami peningkatan keterbukaan diri sebesar 46 hasil Posttest yang berada pada kategori rendah. Responden 10 dengan skor Pretest sebesar 64 berada pada kategori cukup juga tetap tidak mengalami peningkatan kebiasaan belajar sebesar 66 hasil Posttest yang tetap berada pada kategori cukup.

Responden 11 dengan skor Pretest sebesar 30 berada pada kategori rendah juga tetap tidak mengalami peningkatan keterbukaan diri sebesar 35 hasil Posttest yang berada pada kategori rendah. Responden 12 dengan skor Pretest sebesar 49 berada pada kategori rendah juga tetap tidak mengalami peningkatan kebiasaan belajar sebesar 51 hasil Posttest yang berada pada kategori rendah. Responden 13 dengan skor Pretest sebesar 46 berada pada kategori rendah juga tetap tidak mengalami peningkatan kebiasaan belajar sebesar 47 hasil Posttest yang berada pada kategori rendah. Responden 14 dengan skor Pretest sebesar 55 berada pada kategori rendah juga tetap tidak mengalami peningkatan kebiasaan belajar sebesar 57 hasil Posttest yang berada pada kategori sedang. Responden 15 dengan skor Pretest sebesar 63 berada pada kategori cukup juga tetap tidak mengalami peningkatan kebiasaan belajar sebesar 64 hasil Posttest yang berada pada kategori cukup. Responden 16 dengan skor Pretest sebesar 45 berada pada kategori rendah juga tetap tidak mengalami peningkatan kebiasaan belajar sebesar 48 hasil Posttest yang berada pada kategori rendah.

Jika dianalisis dari ke-32 subjek penelitian yang telah dipaparkan di atas tentang peningkatan kebiasaan belajar siswa maka dapat dilihat bahwa dalam kelompok eksperimen terdapat 16 orang siswa yang mengalami peningkatan kebiasaan belajarnya, namun masih ada 16 orang siswa yang tidak mengalami perubahan yang terdapat dalam kelompok kontrol.

Hasil pengujian hipotesis di atas yang menunjukkan adanya pengaruh positif penggunaan teknik problem solving dalam meningkatkan kebiasaan belajar siswa di SMA Negeri I pangkep, yang dilakukan sebanyak 7 tahap terhadap kelompok ekperimen. Dengan kata lain, bagi siswa yang diberi teknik problem solving memiliki kecenderungan kebiasaan belajar siswa di SMA Negeri I pangkep dibandingkan 
kelompok kontrol sebagai kelompok siswa yang tidak diberi teknik problem solving.

\section{Pembahasan}

Kebiasaan belajar merupakan tingkah laku dalam belajar yang terbentuk karena dilakukan secara berulang-ulang dalam hidup siswa, dan biasanya mengikuti cara atau pola tertentu dan dilakukan secara efektif melalui tiga aspek, yaitu keteraturan, disiplin dan konsentrasi sehingga akan terbentuk kebiasaan belajar yang efektif sepanjang waktu. Burghardt (Syah,1997: 118) mengemukakan pula pendapatnya bahwa kebiasaan belajar adalah suatu pola baru dalam bertingkah laku yang relatif menetap dan otomatis yang timbul akibat proses penyusutan kecenderungan respons dengan menggunakan stimulasi yang berulang-ulang.

Sikap dan kebiasaan belajar sebagai suatu rangkaian aktifitas belajar sangatlah kompleks, karena disamping melibatkan aktivitas mental-fisik juga dipengaruhi berbagai unsur lain di luar dan individu yang belajar. Sikap dan kebiasaan belajar siswa yang mempunyai hasil belajar rendah menampakkan sikap dan kebiasaan belajar yang cenderung negatif berbeda dengan sikap dan kebiasaan belajar siswa yang mempunyai hasil belajar yang tinggi. "Sikap dan kebiasaan belajar yang baik akan menghasilkan hasil belajar yang baik pula dan sebaliknya sikap dan kebiasaan belajar yang negatif akan menghasilkan hasil belajar yang rendah

Bersikap dan berkebiasaan buruk dalam belajar, yaitu kondisi siswa yang kegiatan atau perbuatan belajarnya sehari-hari antagonistik dengan yang seharusnya, seperti suka menunda-nunda tugas, mengulur-ngulur waktu, membenci guru, tidak mau bertanya untuk hal-hal yang tidak diketahuinya, dan sebagainya.

Walaupun tingkat kebiasaan belajar siswa sangat penting namun dalam kenyataannya secara umum siswa SMA Negeri I pangkep memilliki tingkat kebiasaan belajar yang rendah, khususnya saat Pretest atau sebelum diberikan perlakuan berupa latihan pemecahan masalah.

Hasil penelitian menunjukkan bahwa terhadap kelompok eksperimen dan kelompok kontrol saat Pretest secara umum menunjukkan tingkat kebiasaan belajar siswa dalam kategori rendah. Namun demikian, untuk kelompok eksperimen yang telah diberi perlakuan berupa teknik problem solving sebanyak 7 tahap, ternyata menunjukkan dampak positif yang cukup baik. Hal ini disebabkan karena tingkat kebiasaan belajar mengalami peningkatan dari kategori rendah menjadi meningkat. Lain halnya dengan kelompok kontrol yang sama sekali tidak diberikan perlakuan berupa teknik problem solving ternyata tidak menunjukkan peningkatan yang berarti atau tetap kategori rendah, walaupun terdapat sebagian kecil responden yang telah memiliki kebiasaan belajar cukup tinggi berdasarkan hasil angket, hal ini disebabkan karena siswa yang diberi teknik probem solving diberikan informasi tentang bagaimana memecahkan masalah secara sistimatis untuk mengetahui alternatif pemecahan masalah berkaitan dengan kebiasaan belajar siswa yang rendah untuk ditingkatkan.

Berdasarkan analisis statistik deskriftif tersebut, dapat dianalisis bahwa pada hakikatnya terdapat peningkatan kebiasaan belajar bagi kelompok eksperimen yang telah diberikan perlakuan teknik problem solving, yaitu dapat dilihat bagaimana siswa mampu mengidentifikasi dan merumuskan masalahnya sendiri, mendiskusikan sebabsebab masalah, mencari alternatif pemecahan masalah dan melaksanakannya yang dilakukan dalam suasana kelompok.

Sedangkan kelompok kontrol yang tidak diberikan teknik problem solving tidak menunjukkan peningkatan yang berarti, dimana hal tersebut diperkuat dengan hasil pengujian hipotesis yang menunjukkan adanya pengaruh teknik problem solving 
dalam meningkatkan kebiasaan belajar siswa di SMA Negeri I pangkep .

Hasil penelitian diatas menunjukkan bahwa teknik problem solving merupakan teknik dalam bimbingan kelompok yang dapat membantu siswa mengajarkan bagaimana memecahkan masalah secara sistimatis mulai mengidentifikasi dan merumuskan masalah, sampai menemukan alternatif pemacahan masalah berkaitan dalam meningkatkan kebiasaan belajarnya.

\section{SIMPULAN DAN SARAN}

Hasil penelitian mengenai pengaruh teknik Problem Solving dalammeningkatkan kebiasaan belajar siswa di SMA Negeri I pangkep , disimpulkan sebagai berikut :

1. Tingkat kebiasaan belajar siswa di SMA Negeri I pangkep hasil Pretest baik kelompok eksperimen maupun kelompok kontrol pada umumnya kategori rendah. Namun demikian siswa yang telah diberi teknik Problem Solving menunjukkan peningkatan kebiasaan belajar menjadi kategori tinggi, sedangkan bagi siswa yang tidak diberi teknik problem solving tidak mennjukkan peningkatan atau tetap dalam kategori rendah.

2. Ada pengaruh teknik Problem Solving dalam meningkatkan kebiasaan belajar siswa di SMA Negeri I pangkep . Artinya, bagi kelompok siswa yang diberikan teknik problem solving, kebiasaan belajar menunjukkan peningkatan dibandingkan dengan kelompok siswa yang tidak diberikan teknik Problem Solving.

Sehubungan kesimpulan penelitian diatas, maka diajukan saran-saran sebagai berikut: (1). Mengingat teknik Problem Solving sebagai teknik bimbingan kelompok dalam kegiatan bimbingan dan konseling masih jarang dilaksanakan di sekolah, sedangkan telah terbukti bahwa teknik Problem Solving dapat meningkatkan kebiasaan belajar siswa, maka disarankan hendaknya konselor sekolah dapat melaksanakan teknik Problem Solving secara terprogram dan bekerjasaa dengan pihakpihak yang terkait. (2). Kepada para guru di sekolah, hendaknya dapat bekerjasama dengan konselor dalam pelaksanaan teknik bimbingan kelompok yaitu teknik Problem Solving, sehingga masalah-masalah yang berhubungan dengan bidang studi dapat dicari alternatif pemecahan masalahnya. (3). Bagi konselor harus lebih memperhatikan hal-hal dalam pelaksanaan metode Problem Solving. (4). Peneliti menganggap dalam pelaksanaan teknik Problem Solving yaitu konselor memperhatikan waktu yang digunakan dalam pelaksanaan teknik ini sehingga tujuan dari pelaksanaan teknik Problem Solving dapat tercapai.

\section{DAFTAR RUJUKAN}

Arikunto, S. (1998). Prosedur Penelitian Suatu Pendekatan Praktik. Jakarta: Rineka Cipta

Chaplin, J.P. (1968). Kamus Lengkap Psikologi. Terjemahan oleh Kartini Kartono. 2006. Jakarta: Rajawali Pers.

Corey, G. (2007). Teori dan Praktek Konseling dan Psikoterapi. Terjemahan oleh E. Koeswara. Bandung: Refika Aditama.

Djamarah, S.B. (2006). Strategi BelajarMengajar. Jakarta: Rineka Cipta

Hadi, S. (2000). Statistik, Jilid 2. Jogyakarta: Andi Offset.

Mahmud, A\& Sunarty, K. (2008). Modelmodel Bimbingan dan Konseling.

Makassar: Panitia Sertifikasi Rayon 24 UNM.

Maulana. (2009). Problem Solving. (http://www.e-iman.uni.cc, diakses 2 oktober 2009)

Manrihu, M.T. (2004). Panduan Penulisan Skripsi Jurusan Psikologi UNM. Makassar: Penerbit Ombak.

Priyatno. (2008). Mandiri Belajar Statistical Product dan Sevice Solution untuk Analisis Statistik dan Uji Statistik. Jakarta : Media Com.

Prayitno \& Amti, E. (1999). Dasar-dasar Bimbingan dan Konseling. Jakarta: Rineka Cipta. 
Ridwan. (2007). Dasar-Dasar Statistika.

Bandung : Alfabeta

Romlah, Tatiek (1989). Teori dan Praktek

Bimbingan Kelompok. Jakarta:

Depdikbud. Ditjendikti.

Sardiman, A,M. (1986). Interaksi \& Motivasi Belajar Mengajar. Jakarta: Raja Grafindo Persada.

Sugiono. (2000). Statistika untuk Penelitian. Bandung: CV. Alfabeta.

Singgih. D.G. (2004). Tips-tips kebiasaan belajar. (www.sabda.com, diakses 30 September 2009)

Sukardi, D,K. (2000). Pengantar Pelaksanaan Program Bimbingan \& Konseling Di Sekolah. Jakarta: Rineka Cipta.

Surya, M. (2003). Teori-Teori Konseling. Bandung: Bani Quraisy

Thantawy. R. M. A. (1993). Kamus Bimbingan dan Konseling. Jakarta: Economics Student's Group

Tiro, (2004). Dasar-dasar Statistik. Ujung Pandang: UNM.

Yusuf, S.(2006). Program Bimbingan dan Konseling Di Sekolah (SLTP Dan SLTA). Bandung: Bani Quraisy.

Walgito, B. (2007). Psikologi Kelompok. Yogyakarta: CV. Andi Offset. 